\title{
Dialogioppiminen ryhmä- ja yksilötasoilla hoitotyön kontekstissa
}

Anneli Sarja

Dialogi on usein ymmärretty kapea-alaisesti kahden ihmisen välittömänä kielellisenä kanssakäymisenä kasvotuksin. Tässä artikkelissa dialogi on käsitteellistetty kasvokkaissuhdetta laajemmin kulttuurisena ilmiönä. Tällöin myös kielellisen vuorovaikutuksen ylikielellisillä eli historiallisilla piirteillä on merkitystä dialogin kehittymiselle. Tästä näkökulmasta erilaiset arjen käytänteet ja niiden synnyttämät ristiriidat ovat dialogioppimisen hedelmällinen lähtökohta, koska samaan tilanteeseen sitoutuvilla ihmisillä on erilaista tietoa.

Vuorovaikutteisesta, keskustellen etenevästä dialogioppimisesta on tullut tiimityön yleistymisen myötä keskeinen opiskelumuoto aikuiskoulutuksessa. Sen on nähty laajentavan uudella tavalla niin ohjaajan ja opiskelijan välistä kuin opiskelijoiden keskinäistäkin tasa-arvoisuutta ja avoimuutta. Keskeisenä tavoitteena dialogissa on ollut vaiheittainen jaetun ymmärryksen rakentaminen. Jakaminen on yleensä merkinnyt ihmisiä yhdistävien piirteiden korostumista (Fernandez-Balboa \& Marshall 1994, Tillema 1997).Toiset ryhmän jäsenet ja ohjaaja ovat tarjonneet ikään kuin dialogiset puitteet yksittäisen jäsenen oman työn ja persoonan reflektiiviselle arvioinnille.

Dialogioppiminen on usein myös ymmärretty kapea-alaisesti vain kahden ihmisen välittömänä kielellisenä kanssakäymisenä kasvotuksin. Tässä ar- tikkelissa dialogioppiminen on kuitenkin käsitteellistetty kasvokkaissuhdetta laajemmin kulttuurisena ilmiönä. Tällöin myös kielellisen vuorovaikutuksen ylikielellisillä eli historiallisilla piirteillä on merkitystä sen kehittymiselle. Tästä näkökulmasta erilaiset arjen käytänteet ja niiden synnyttämät jännitteet ovat dialogioppimisen hedelmällinen lähtökohta, koska samaan tilanteeseen sitoutuvilla ihmisillä on erilaista tietoa ja kiinnostuksen kohteita. (Johnson 1997, Lave 1993, 15).

Käytäntöpainotteisena opiskelujaksona opetusharjoitteluvaihe tarjoaa hyvät mahdollisuudet dialogin käyttöön. Tässä vaiheessa opiskelijat voivat hyödyntää aiemmin hankkimaansa asiantuntemusta uuden tiedon opiskelussa. Artikkelissa kuvataan yhden opettajaopiskelijaryhmän 
dialogioppimisen prosessia terveydenhuollon opettajankoulutuksessa. Tarkastelun kohteena on myös se, miten yksittäinen opettajaopiskelija käyttää ryhmädialogin tuottamaa tietoa oman oppimisensa jäsentämisessä eli "itsensä johtamisessa".

\section{Dialogioppimisen teoreettista taustaa}

$\mathrm{P}$ edagogisissa yhteyksissä dialogi on saanut erilaisia ilmenemismuotoja siitä riippuen, millainen oppimis- ja tietokäsitys sen taustalta löytyy. Esimerkiksi Mezirowin (1995) emansipatorisen eli itseohjautuvan oppimisen teoriassa yksilöllisen tietoisuuden ja itsekäsityksen kehitys on kytketty dialogiin. Dialogioppimisen tarkoituksena on pidetty toisten ryhmän jäsenten lausumien merkitysten tulkitsemista ja ymmärtämistä. Dialogin kautta yksilöt tulevat kuitenkin vähitellen tietoisiksi paitsi toisten myös omasta ajattelustaan. Rationaalissävytteinen dialogi ei kiinnity kuitenkaan jokapäiväisen elämän arkikäytänteisiin vaan sen kautta pyritään tulemaan tietoiseksi omaa toimintaa ja ajattelua rajoittavista tekijöistä. Dialogioppiminen auttaa siihen osallistuvia kohtaamaan niitä sisäisiä jännitteitä, joita heidän tapaansa käsitellä todellisuutta sisältyy. (Mezirow 1995.)

Mezirowilaisittain ymmärretyssä dialogioppimisessa liikutaan yksilöllisen toiminnan perusteiden reflektiivisessa tulkinnassa konkreettisten arkikäytänteiden kriittisen arvioinnin sijasta. Dialogioppimisen tavoitteena on toisten ihmisten erilaisten intentioiden ymmärtäminen, minkä vuoksi dialogissa on tärkeää luoda suotuisa, toisen oppimista tukeva ilmapiiri. Dialogioppimisen lopullisena pyrkimyksenä on koherenssin saavuttaminen omaksumistamme kulttuurisesti määräytyneistä käsityksistä ja uskomuksista. Konsensuaalisen pätevöittämisen kautta dialogissa pyritään löytämään totuuksia, vaikka niitä ei pidetäkään lopullisina. Näin määriteltynä dialogi yhdistää ihmisiä maailmaan ja muihin ihmisiin. Se luo myös jaettua ymmärrystä. Tällaisessa dialogisessa suhteessa vuorovaikutuksen kohde (kulttuuriset artefaktit) on kuitenkin kiinteäm- min sidoksissa ulkomaailmaan kuin yksittäiseen yksilöön (Prawat 1996). (Mezirow 1995.)

Kontekstuaalisissa oppimiskäsityksissä oppimisen kohteeksi on rajattu oppimisympäristö, reaalitodellisuus ja sieltä nousevat ongelmat. Reflektiivisen ajattelun merkitys korostuu myös rutinoitujen toimintakäytäntöjen uudistamisessa. Reflektio kohdistuu näissä teorioissa kuitenkin yksittäisten toimintakäytäntöjen sijasta kokonaisten toimintajärjestelmien uudistamiseen.

Tällaisen oppimisen edellytyksen muodostavat ryhmän jäsenten erilaiset näkökulmat ja niistä johtuvat jännitteet (Hakkarainen, Helenius \& Jääskeläinen 1999, 26). Toimintakäytäntöjä uudistavaan oppimiseen liittyy Kaupin $(1993,84)$ mukaan ulkoistaminen, uuden tietoperustan tuottaminen, toimintakäytäntöjen kehittäminen ja niiden reunaehtojen uudelleenmäärittely. Kun oppimista analysoidaan käytännöllisen toiminnan tasolla, siirrytään yksilö- ja ryhmäoppimisen tasoilta yhteisöllisen oppimisen tasolle. (Engeström 1987, Kauppi 1993.)

Yhteisöllistä oppimisen tasoa edustavat koulutuksessa teoreettiset käsitteet, koska niihin kiteytyy kulttuurista, opetussuunnitelmassa määriteltyä tietoa. Kulttuurin kehitys näkyy kielessä. Tämä merkitsee erityisesti historiallisten piirteiden korostumista puheessa ja sen analyysissa. Historiallisesti "kerrostunut konteksti" esiintyy teoreettisissa käsitteissä samanaikaisina, eri ajoilta peräisin olevina painotuksina. Näin samakin käsite voi saada erilaisia merkityssisältöjä eri oppimistilanteissa. Oppimisen tarkastelu kontekstuaalisena ilmiönä ankkuroituu Vygotskin (1978, 
57) "välittyneen toiminnan" ajatukseen, jonka mukaan käsitteet ovat välineitä arkitodellisuuden tulkinnassa ja muuttamisessa.

Käsitteiden kehityksessä ja samalla myös dialogioppimisen analyysissa onkin erotettava itse asiassa kaksi toisiinsa yhteydessä olevaa tasoa: ulkoinen ja vakaa, valmiina annettu sekä dynaaminen ja luova, kulloisessakin oppimistilanteessa muodostettu merkitystaso. Ensimmäisellä merkityksen tasolla käsitteet omaksutaan autoritaarisina "sanakirjasanoina". Käsitteiden hankittu empiiris-dialoginen merkityssisältö paljastuu vasta konkreettisessa toiminnassa ja puheessa. Bahtin (1987) nimittää jälkimmäistä merkityksen tasoa “ääneksi” ja tarkoittaa sillä niitä erilaisia henkilökohtaisia kokemuksia, tuntemuksia ja mieltymyksiä, joita käsite yksilössä dialogin tuloksena synnyttää. Näin psyykkisetkin prosessit ovat sidoksissa toimintaympäristöön, kun samakin puhuja saattaa omaksua yhden keskustelun aikana useita identiteettejä eli moniäänisyyttä. (Engeström 1999, Kauppi 1993, 56).

Kontekstuaalisen dialogioppimisen kannalta keskeistä on se, että ryhmä rajaa yhteisen tarkastelun kohteekseen saman käsitteen (Grosz 1981, Vella 1994). Rajaamisessa on kyse yhteisen oppimisen kohteen tietoisesta muodostamisesta. Kohteella tarkoitetaan sellaista rajattua asiasisältöä, josta dialogiin osallistujat voivat esittää erilaisia perusteltuja tulkintoja tai käsityksiä. Esitettyjä erilaisia ääniä kehitellään dialogin aikana. Dialogin kielellinen puoli tuo kuitenkin esiin vain osan lausuman merkityssisällöstä. Ei-kielellinen puoli lausumasta on yhteydessä puheen kontekstiin, erilaisten ja usein myös ristiriitaisten elämänkäytäntöjen eli moniäänisyyden esiintymiseen samassa lausumassa (Volosinov 1990, 106107). Dialogioppimisen analyysi edellyttää oppimisen kohteeksi rajatun ongelmakokonaisuuden historiallista analyysia. Sen avulla pyritään jäljittämään erilaisia oppimis- ja hoitamiskäsityksiä ja niihin kytkeytyviä puheenmuotoja, joita terveydenhuollon opettajakoulutuksessa on sen historian kuluessa esiintynyt (ks. tarkemmin Sarja 2000).

Dialoginen lausuma kytkeytyy siis osaksi sitä his- toriallista, yhteisöllistä ja sosiaalista kokonaisuutta, jossa dialogin osapuolet toimivat. Bahtinin (1981, 293-294) mukaan emme voi vapaasti valita sanojamme vaan puhe on aina puoliksi jonkun toisen. Tuotamme näin joko huomaamattamme tai tiedostetusti jo aiemmin tuotettua eri aikakausina kehittynyttä ns. historiallista puhetta. Oppimisympäristökeskeisissä oppimisteorioissa käsitys vuorovaikutuksesta perustuu dialogiseen vastakkainasetteluun. Bahtin (1981) korostaa, että dialogi on jatkuvaa taistelua vastakkaisten, monologin erottavien (centrifugal) ja dialogin yhdistävien (centripetal) voimien välillä. Se ei ole pyrkimystä yhdenmukaisten näkemysten aikaansaamiseen. Tämän vuoksi dialogin keskeinen piirre on ihmisten välinen kriittisyys, erilaisuuksien vastavuoroinen huomioonottaminen mutta tarvittaessa myös kyseenalaistaminen.

Kontekstuaalisen dialogioppimisen tavoitteena on, että koko ryhmä muuttuu luomalla jaetun kohteen opittavasta asiasisällöstä sen omassa toimintajärjestelmässä. Dialogioppimisessa ensisijaisena tutkimuskohteena ei ole näin ollen yksilön oppiminen ryhmässä, vaan koko ryhmän oppiminen laajemmassa organisaatiossa. Kohde voi jäädä jaetuksi, mutta se voi kehittyä myös yksilöllisen reflektion tuloksena. Rogoff $(1995,153)$ nimittää tätä oppimisen tasoa osallistuvan omaksumisen vaiheeksi ja ymmärtää sillä ryhmän/yksilön ja yhteisön välisen rajan kyseenalaistumista. Dialogioppimisen tuloksena ryhmä (tai yksilö) pystyy tunnistamaan, kritisoimaan ja uudelleentulkitsemaan ulkoisia toimintansa kohteita (Johnson 1997). Dialogioppiminen merkitsee näin oppimisen kohteena olevan asian (ja myös erilaisten näkökulmien) yhdistämistä systemaattiseksi kokonaisuudeksi ja tämän kokonaisuuden tietoista ylittämistä uuden tiedon ja uusien käsitteiden muodossa. Erilaisten arkikäytännössä kohdattujen ongelmatilanteiden ratkaisun avulla on mahdollista tuottaa uusia aikanaan tieteelliseksi muuttuvia käsitteitä. (Bateson 1972, Engeström et al. 1995.)

\section{Aineistonkeruu ja dialogioppimisen analyysi}

Tutkimus kohdistui ryhmään opettajaopiskeli- 
joita (kolme terveydenhuollon kandidaattiopiskelijaa). Opettajaopiskelijaryhmä suunnitteli ja toteutti itsenäisesti oppikurssin kuolevan potilaan hoidosta. Suunnitelun apunaryhmä käytti mallintamisen menetelmää. Se mahdollisti oppisisällön tarkastelun systeemisenä kokonaisuutena, mikä tarkoittaa kuolevan potilaan hoidon keskeisten käsitteiden välisten suhteiden tietoista muuntelua. Mallin avulla opiskelijaryhmä pystyi täten paikallistamaan kuolevan potilaan hoidon kriittisiä vaiheita. Huomattava on, että ryhmän jäsenillä oli usean vuoden käytännön kokemus kuolevan potilaan hoidosta, joten erilaisia arjen kokemuksia voitiin hyödyntää teoriamallin työstämisessä. Huomattava on myös se, että ohjaajat osallistuivat tasavertaisesti yhteisen teoriamallin suunnitteluun. Dialogioppimista pyrittiin näin tietoisesti tuottamaan yhteisen oppimistehtävän avulla. (Hakkarainen \& Janhonen 1997.)

Opettajaopiskelijaryhmän dialogioppimista analysoitiin tutkimuksessa kolmessa opetusharjoittelujakson vaiheessa: oppikurssin suunnittelussa, ohjaus- ja arviointikeskustelujen aikana sekä opetuksessa. Tutkimustehtävänä oli selvittää, millaisten dialogien avulla rakennetaan uutta tietoa (jaettu oppimisen kohde) erilaisissa ryhmä- ja yksilöoppimisen tilanteissa. Tarkastelu kohdistui sekä opiskelijatiimin keskinäisiin dialogeihin että opiskelijatiimin ja heidän ohjaajiensa välisiin dialogeihin. Lisäksi analysoitiin opettajaopiskelijoiden ja heidän oppilaidensa välisiä dialogeja. Tällöin dialogioppimisen analyysissa keskityttiin ainoastaan siihen, miten yksittäinen opettajaopiskelija hyödyntää dialogioppimisen tuottamaa tietoa omassa opetuksessaan. Tässä artikkelissa dialogioppimista analysoidaan pääasiallisesti opiskelijaryhmän ja sen yksittäisten jäsenten näkökulmasta.

Tutkimuksessa kehitettiin dialogioppimisen analyysia varten erillinen malli, jolla voitiin jäljittää dialogioppimisen onnistuminen tai siinä mahdollisesti esiintyvät puutteet. Mallia on kuvattu yksityiskohtaisemmin toisaalla (Sarja \& Janhonen 1999, Sarja 2000). Mallissa erotettiin kolme toisiinsa yhteydessä olevaa jaksoa: yhteisen kohteen (asiasisällön) rajaamisvaihe, erilaisten äänten esiintuomisvaihe sekä asiakokonaisuuden hahmottaminen täysin uudesta näkökulmasta. Dialogin käynnistymisen kannalta keskeistä on aiheen selkeä rajaaminen jo alkuvaiheessa. Kohteen rajaamisella tarkoitetaan vaihetta, jolloin ryhmän jäsenet päätyvät yhteisymmärrykseen siitä, mistä asiasta halutaan käydä dialogia. Yhteisen kohteen tietoinen luominen merkitsee kohteen moniäänistä tulkintaa, merkityksen yhteistä konstruointia (Markova \& Linell 1996). Dialogioppimisen lopullisena tavoitteena ei ole yhteisymmärryksen aikaansaaminen, vaan dialogi jää usein lopputulokseltaan täysin avoimeksi. Seuraavassa havainnollistan edellä lyhyesti määrittelemääni kahta erilaista dialogioppimisen tapaa.

\section{Kriittinen ja reflektiivinen dialogi hoitotyön oppimisessa ja opetuksessa}

$\mathrm{D}$ ialogioppiminen osoittautui tutkimuksen erusteella harvinaiseksi, mikäli se ymmärrettiin arkitodellisuudesta nousevien ongelmien uudenlaiseksi jäsentämiseksi. Äänianalyysin avulla aineistoista erottui kaksi dialogioppimisen tapaa, jotka nimesin kriittiseksi ja reflektiiviseksi dialogiksi. Yhteistä molemmille oli se, että keskustelun kohteeksi rajautui jokin käytännön ongelmatilanne. Kriittisessä dialogissa osallistujat paljastivat avoimesti omat näkökulmansa yhteisestä oppimisen kohteesta, eikä näitä edes pyritty sulauttamaan toisiinsa vaan käytettiin hyväksi ongelman tarkastelemiseen monista lähtökohdista. Sen tavoitteena oli kokonaan uuden tiedon tuottaminen käsillä olevasta ongelmakokonaisuudesta. Kriittinen dialogi jäi kuitenkin usein puolitiehen. Reflektiivinen dialogi kiinnittyi selvemmin yksilöllisiin oppimistilanteisiin. Siinä myötäiltiin herkemmin toisten näkemyksiä, minkä vuoksi sen tuloksena ryhmän jäsenten erilaisia näkemyksiä yhdistettiin toisiinsa ja siten tuotettiin yhteistä, jaettua tietämystä.

\section{Dialogioppiminen ryhmätasolla}

Opettajaopiskelijaryhmä pystyi oppikurssin suunnitteluvaiheessa sisällöllisesti korkeatasoiseen ja uudistavaan keskusteluun, mutta dialogioppimi- 
sen tuottamaa tietämystä ei yleensä hyödynnetty yhteisen oppimisen lähtökohtana myöhemmin opetustilanteissa arkisia ongelmia ratkottaessa. Käytäntö ja teoria olivat harvoin vuorovaikutuksessa keskenään. Seuraava lyhennelty esimerkki havainnollistaa dialogioppimista oppikurssin suunnitteluvaiheessa. Katkelmassa kolme opettajaopiskelijaa tuo rohkeasti esiin eriävän äänensä keskustelun kohteeksi aiemmin rajaamastaan hoitajan ammatillisen kasvun käsitteestä. Kriittisen dialogin tuloksena opiskelijaryhmä kehittää jaettua tietämystä hoitajan ammatillisuuden ulottuvuuksista, vaikka yhteistä dialogin kohdetta ei tarkastellakaan täysin uudesta näkökulmasta.

Opiskelija 1: Aika voimakkaasti näyttää tämä lääketieteellinen tieto olevan sitä, mitä ne kokee tärkeäksi. Ei niinkään hoitaminen

Opiskelija 2: Sen huomaa tässä vaiheessa, että se vapauttaa kuitenkin energiaa muuhun. Kun siihen potilaan hoitamiseen ei mene enää energiaa. ... Olen opiskelijoiden kanssa samaa mieltä. Sairaus täytyy tietää. Et voi seurata sitä, jos et tiedä esimerkiksi maksakoomaisesta potilaasta, että sen tajunnan taso on yksi merkki sen kooman syvenemisestä sen sairauden etenemisessä. Silloin kun hallitsee lääketieteellisen tiedon, vapautuu energiaa siihen potilaan hoitamiseen

Opiskelija 3: Ne paikkaa toinen toisiansa. Mukamas lääketieteellisen tiedon pohjalta tarkkaillaan. Jos et potilaan kanssa pysty minkäänlaiseen vuorovaikutukseen. ... Säästäisit hirveästi energiaa, kun kysyisit siltä suoraan, mitä sille kuuluu. Se luettelisi sulle tulemaan. Sen sijaan, että yrität kerätä tietoa ja tarkkailla sitä. ... Ei tarvitsisi mistään kaivaa eikä etsiä.

Opiskelija 1: Lääketieteellistä tietoa voi koko ajan tarkistaa lääkäriltä, jos ei osaa itse. Minusta tulisi tukea sitäkin, että jos olet hoitotyön alueen omaksunut ja sulla on ne vuorovaikutustaidot. Sinä voit tarkistaa vuorovaikutuksen avulla omia tietoja kirjoista.

Opiskelija 2: Mutta kun he ovat ammattitaitoisia hoitajia, niin kyllä heillä täytyy minusta olla ne tietyt perusasiat. ... Ei siinä kerkiä kirjasta katsomaan, että miten tätä hoidetaan. Kyllä se täytyy olla vahva tieto ja kokonaisuus sairauden hoidosta, miten se esimerkiksi vaikuttaa psyykkeen ja miten kokonaispersoonallisuus muuttuu sairauden aikana.

Opiskelija 3: Ajattelen sitä omalta henkilökohtaiselta kasvualustaltani niin päin, että aluksi kun oli epävarma, meni valtavasti energiaa vuorovaikutukseen. Ei osannut käyttää sitä lääketieteellistä tie- toa, minkä omasi. Sitten kun oppii puhumaan asiakkaiden kanssa, oppii olemaan turvallinen siinä omassa vuorovaikutuksessa ja sen jälkeen vapautuu hirveästi energiaa sen lääketieteellisen tiedon käyttöönkin. Niille pitää tuoda molemmat näkökulmat rinnakkain. ... Että on olemassa monta tapaa nähdä sama asia.

Opiskelija 2: Minun kasvuni on käynyt sitä tietä, että mun on ensiksi täytynyt opiskella käden taidot ja tietynlaiset hallinnat ja ymmärtää, ennen kuin olen pystynyt vapauttamaan energiaa potilaan kokonaisvaltaiseen hoitoon

$\mathrm{D}_{\mathrm{s}}$ ialogikatkelma kiinnittyy hoitotyön arkeen erityisesti lääketieteellisen ja hoitotieteellisen tiedon suhteeseen hoitajan jokapäiväisessä työssä. Jokainen dialogiin osallistuja tarkastelee yhteistä dialogin kohdetta omasta näkökulmastaan, vaikka lausumissa onkin viitteitä toisen näkökulman huomioonottamisesta. Merkittävää on, että dialogi jää avoimeksi, kun sisällöllisen toteutuksen lähtökohdaksi päätetään ottaa molemmat näkemykset hoitamisesta. Dialogissa muodostetaan näin jaettua tietämystä hoitajan ammatillisuuden erilaisista ulottuvuuksista. Dialogioppimisen tuloksena ryhmä havaitsee, että ammatillisesti voi kasvaa monella tavalla ja että kasvuun vaikuttaa hoitajan kulloinenkin elämäntilanne ja hoitoympäristö.

Opiskelijoiden vastakkaisissa lausumissa on erotettavissa erilaisia ääniä, erilaisia käsityksiä siitä, mikä hoitotyössä on tärkeää. Toisessa niistä painottuu hoitajan hoitotaidon ääni, toisessa potilaan itsehoitoajattelun ääni. Esimerkiksi opiskelijoiden 1 ja 3 näkökulmat kuvastavat jälkimmäistä hoitonäkemystä, jonka mukaan hoitaja on palvelujen tarjoaja, potilaan tukija, ymmärtäjä ja avustaja. Tällaisessa näkemyksessä vuorovaikutus saa supportiivisia, toisen ajatuksia ja puhetta myötäileviä piirteitä. Dialogisessa yhteistyösuhteessa hoitaja ei pyri muuttamaan toista omien mielikuviensa mukaiseksi vaan yrittää toisen yksilön, potilaan, avulla vajota omaan minäänsä kuunnellakseen omia tunteitaan ja tullakseen tietoiseksi niistä. Tällaisessa potilaan itsehoidollisuutta korostavassa suhteessa potilas on oman hoitonsa subjekti ja hoitaja toimii pelkästään avustajana. Potilaan yksilölliset tunteet ja tarpeet ohjaavat hoitokeinojen ja menetelmien valintaa. (Noppari ym. 1996.) 
Opiskelijan 2 näkökulma on sidoksissa katalyyttisempaan, potilaan ja hoitajan välistä yhteistyötä sekä hoitamisen asiantuntijuutta korostavaan hoitamiskäsitykseen. Auttamismenetelmänä tässä hoitotyön näkemyksessä on osallistuva dialogi, mikä merkitsee hoitajan vastuun korostumista erityisesti hoitotyön ristiriitatilanteissa. Hoitokäytännössä ristiriitaa aiheuttavat mm. lääketieteen ja hoitotieteen erilaiset intressit, mikä näkyy kuolevan potilaan hoidossa hoitajan ja lääkärin päällekkäisinä vastuukysymyksinä. Hoitajan aktiivisuus ilmenee oman tilannekohtaisesti vaihtelevan käyttöteorian luomisena. Tällöin hoitajan puheessa ja toiminnassa keskeinen merkitys on hoitotyön rutinoitujen toimintakäytäntöjen kyseenalaistaminen. Erityisesti kuolevan potilaan hoidossa hoitaja joutuu ylittämään perinteisen osaamisensa rajoja hoidon keskeisen tavoitteen, hyvän kuoleman mahdollistumiseksi. (Janhonen \& Pyykkö 1996.)

Edellisessä esimerkissä dialogioppiminen ei tuota uutta tietoa, vaikka hoitajan toiminnallisia rutiineja kyseenalaistetaankin. Onkin huomattava, että ryhmädialogin tuottama muutos saattaa näkyä vasta jonkin ajan kuluttua varsinaisesta oppimistilanteesta, jolloin sitä on vaikea havaita dialogioppimisen analyysissa. Tämän vuoksi dialogioppimisen analyysia on syytä jatkaa myös yksilöllisissä oppimistilanteissa. (Draper \& Anderson 1991.)

\section{Dialogioppiminen yksilötasolla}

Y ksilöllisen oppimisen tasolla, opetuksen toteutusvaiheessa, dialogioppiminen kiinnittyi hoitotyön kulminaatiovaiheisiin. Kriittiseksi nimettyä dialogia edisti se, että arjen ongelmatilanteita tarkasteltiin toiminnallisissa yhteyksissään, organisaatiotasolla. Tällöin opettajaopiskelija rajasi keskeisen hoitotyön ongelmatilanteen yhteisen oppimisen lähtökohdaksi. Hän ohjasi myös oppilaita havainnoimaan asioiden välisiä yhteyksiä vaatimalla heiltä perusteluja vastauksilleen. Reflektiivinen dialogi kiinnittyi sitä vastoin selvemmin yksittäisiin oppimistilanteisiin, jolloin keskustelussa pitäydyttiin enemmän ar- kikokemusten tasolla. Opettajaopiskelija ei rajannut tietoisesti yhteistä oppimisen kohdetta, vaan luotti oppilaidensa itseohjautuvuuteen ongelmatilanteiden jäsentämisessä. Havainnollistan seuraavassa lyhyesti kyseisiä dialogioppimisen muotoja opetuksen suunnittelu- ja toteutusvaiheissa.

Kriittinen dialogi. Alla olevissa esimerkeissä opettajaopiskelija hyödyntää aiempien ryhmädialogien tuottamaa tietoa. Suunnitteluvaiheessa hän rajaa oppimisen kohteeksi keskeisen hoitotyön ongelmavaiheen kuolevan potilaan hoidossa, lääketieteen ja hoitotieteen ristiriitaiset tavoitteet ja toimintakäytänteet. Toteutusvaiheessa palovammapotilaan tarkoituksenmukaista hoitoa lähdetään yhdessä jäsentämään hoitotyön näkökulmasta (hoitolinjan muutos). Dialogin periaatteiden mukaisesti oppilaat saavat itse nimetä keskeiset hoitotyön auttamismenetelmät yhteisen tavoitteen (hyvä kuolema, ei kärsimystä) saavuttamisessa.

Suunnitteluvaihe (5. toukokuuta):

Ohjaaja: Elikkä tästä ei oltu tehty päätöstä, että se on terminaalihoitoa. Eikö tämä todella ole tarkoituksenmukaista hoitoa? ..

Opettajaopiskelija: Ei, minä olen eri mieltä sinun kanssa. Mehän ei voida hoitaa kuin päätöksen takia potilasta. ... Eli hoidettiin potilasta koko ajan väärin. ... Tiedettiin, että potilas tulee menehtymään. ... Oltaisi lievitetty sen kärsimyksiä, kun ei oltaisi tehty niitä kaikkia asioita mitä tehtiin sille potilaalle. Toimenpiteet, jotka tuotti hänelle enemmän kärsimystä. Nyt painotetaan näihin hoitotyön erityispiirteisiin tarkoituksenmukainen hoito päämääränä. Elikkä kun täällä on fysioterapiaa palovammapotilaalle, jolla on selkä palanut, kädet, jalat. Onko enää tarkoituksenmukaista tuottaa potilaalle tuskaa liikeratoja voimistuttamalla. Siinä tipahtaa tällaiset, jotka ei ole potilaan hyvän olon tuottamiseksi tarkoituksenmukaisia. Lääketieteen painotus muuttuu. ... Ehkä täällä vieläkin on ongelmallista kivunhoito, johon lääketieteen täytyy antaa meille koko ajan apua. ... Miten hoitotyöllä tuetaan kärsimystä? Miten meidän pitää keskustella potilaan kanssa? Miten hoitajana käytän omaa itseäni potilaan hoidossa? ... Sitten tarkoituksenmukaisen hoidon lähtökohtana on kulloisellakin hetkellä olevat potilaan tarpeet ja käytettävissä olevat hoitotyön menetelmät. Silloin kivun ja henkisen kärsimyksen lievittäminen on lähtökohtatarpeita tämän potilaan kohdalla. ... Tämä on hoitotyön itsenäisintä aluetta, jota kukaan muu ei toteuta niin täysipainoisesti. Se hoitajalle antaa vapautta, mutta myös vastuuta hoitaa potilasta oman ajattelutavan mukaan. 
Toteutusvaihe (6. toukokuuta):

Opettajaopiskelija: Tämän tunnin toteutus tapahtuu yhden kuolevan potilaan kokonaishoidon tarkastelun kautta. ... Ja alotettiin palovammapotilaan periaatteita ohjaava hoito tiettyyn pisteeseen asti, kunnes huomattiin, että lääketieteellisin keinoin ei voida sairautta parantaa. Tehtiin selkeä hoitolinjan muutos ja päädyttiin hyvään kuolemaan mahdollistavaan hoitoon. ... Ja kun tehtiin hoitolinjan muutos, niin tämä suhde muuttu. Miten se muuttu hoitotyön näkökulmasta, niin nyt tarkotuksena on hahmottaa hoitotyön näkökulmaa potilaan tarpeiden tyydyttämiseksi. ... Erottelette, mikä on olennaista ja mikä epäolennaista siinä kuolevan potilaan hoidossa.

.. Ja lähetään potilaan keskeisistä tarpeista ja mitkä konkreettiset hoitotyön käytännön toiminnat niitä tarpeita palvelevat ja mitä todellisuudessa teemme tämän takia. ... Mietitään, mikä silloin kun tehdään hoitolinjan muutos, niin ett se mahdollistaa potilaan hyvän kuoleman. ... Voisitte käyttää aiemmin opittuja hoitotyön teorioita, malleja, mitä tahansa. ... Voitte luoda uuden. Tärkeää on, että se palvelee teiän hahmottamista tässä tilanteessa.

Oppilas: Ajateltiin tätä potilaan tilannetta mikä se on. Ja koska vääjäämättömästi on kuolema edessä, että mitä tällä hetkellä vois tehdä, että potilaalla olis mahollisimman hyvä olla. Meiltä lähti kaikki toimenpiteet siitä.

- - -

Opettajaopiskelija: Jos vähän syvemmin mietitään yhdessä sitä infektioiden hoitoa ja palovammojen hoitoa. Millä lailla on tärkeää myös täällä se infektioiden ehkäsy ja hoito? Onko se sen takia, että ne vammat paranee? Mikä on täällä perustelu?

Oppilas: Sehän on takana se potilaan hyvän olon tunteen lisääminen kaikilla näillä toimenpiteillä, millä niitä haavojakin hoidetaan.

Oppilas: Ajattelin, että jos iskee päälle joku infektio pitäs periaatteessa turvautua lääketieteelliseen hoitoon ja tutkimukseen elikkä annetaanko sille antibiootteja. Elikkä lisää hoitoa yleensä lisää kärsimystä ...

Opettajaopiskelija: Jos palovamman aste on toista ja kolmatta astetta ja on yli 30 prosenttia, niin tuleeko infektioita?

Oppilas: Siis infektio tulee, jos kuolleella tarpeeksi iho on palanu.

Opettajaopiskelija: Elikkä nämä potilaat kuolevat ensiksi. ... Näin pahasti palaneita potilaita meillä ei ole lääketieteellisin keinoin mahdollista hoitaa. ... Elikkä se perustelu tuli ainakin, että se ois potilaan hyvän olon mahdollistaja. Elikkä kun on puhuttu tästä hoitotyön prosessiajattelusta, niin se on kokonaisuus. Siinä ei voi eritellä potilaan asioita, että koskaan nämä asiat eivät kuvaa sitä todellisuutta ja niitä yhteenliittymiä. Jotakin pieniä osa-alueita voidaan ottaa sieltä ja kuvailla sitä todellisuutta, mikä siitä tulee. Mutta sen selitysvoimaisuus ei ole niin suuri kuin tällä hyvä perushoito-sanalla.... Elikkä palovamma-alueen hoito ei ole keskeisin tekijä, joka ohjaa hoitajan toimintaa vaan hyvän olon tuottaminen ja kärsimysten lievittäminen eli perushoito, se tarpeenmukainen hoito. ... Se on aina yksilöllisestä hoitosuhteesta, hoitosuunnitelmasta, siitä organisaatiosta, kulttuurista riippuvaa, missä ollaan ja potilaan tilasta, pystyykö hän ottamaan osaa päätöksentekoon, osallistumaan hoitoon jne.

Suunnitteluvaiheessa opettajaopiskelija tuo uudelleen esiin hoitotaidon äänen, kun hän kyseenalaistaa tietyt palovammapotilaan hoitotyön rutiinit. Opettajaopiskelija tarkastelee kuolevan potilaan hoitoa osana laajempaa organisatorista kokonaisuutta, jossa hoitajan ammattitaito näkyy omaa toimintaa ohjaavien puitteiden tietoisena säätelynä. Ryhmän yhteinen terminaalihoidon mallin tavoite (hyvä kuolema, ei kärsimystä) ja omat käytännön kokemukset lähtökohtanaan hän rajaa tuskaa tuottavat lääketieteelliset toimenpiteet fyysisen perushoidon ulkopuolelle. Dialogioppimisen tuloksena opettajaopiskelija kehittää tarkoituksenmukaisen hoidon käsitteen, jonka avulla palovammapotilaan hyvää perushoitoa on mahdollista arvioida täysin uudesta näkökulmasta.

Toteutusvaihe käynnistyy induktiivisesti opettajaopiskelijan kuvatessa konkreetteja hoitotyön käytännön toimintoja palovammapotilaan hoidossa. Opettajaopiskelija sitoo konkreetin potilasesimerkin osaksi hoitoyhteisön toiminnallista kokonaisuutta. Hän korostaa hoitajan vastuuta tarjoamalla oppilaille välineen, tarkoituksenmukaisen hoidon käsitteen, kokonaisuuden hahmottumiseksi yhteisestä hoidon tavoitteesta käsin. Oppimisen kohteeksi rajattua palovammapotilaan hoitotyön kokonaisuutta rakennetaan yhdessä. Opettajaopiskelija vaatii opiskelijoilta perusteluja ja kyseenalaistaa niitä tarvittaessa lisäkysymyksin. Niissä oppimisen kannalta kriittisissä vaiheissa, joissa oppilaat eivät pysty erottamaan olennaista epäolennaisesta, hän tarjoaa lisää tietoa kokonaisuuden jäsentymiseksi. Kysymysten avulla hän pyrkii varmistamaan jaetun tietämyksen perustaa, jotta keskustelu voisi edetä seuraavaan vaiheeseen. Dialogioppimisen tuloksena tärkeäksi palovammapotilaan hoidon kriteeriksi kehittyy hoitotyön auttamismenetelmien tilannekohtaisen arvioinnin merkitys.

Reflektiivinen dialogi. Edellisestä esimerkistä poiketen opettajaopiskelija ei hyödynnä suunnittelu- eikä toteutusvaiheissa dialogioppimisen kautta aiemmin hankkimaansa tietämystä. Hän ei rajaa tietoisesti yhteistä oppimisen kohdetta, 
vaikka ohjaaja ja myös oppilaat sitä myöhemmin vaativat. Tästä johtuen dialogioppimisen ensisijaisena lähtökohtana ovat oppilaiden arkikokemukset, kun he havainnoivat kuolevan potilaan tunteita ja tarpeita.

\section{Suunnitteluvaihe (8. toukokuuta):}

Ohjaaja: Mikä on keskeisin oppimisen kannalta tätä ryhmää ajatellen sun mielestä?

Opettajaopiskelija: Keskeisintä on se, että ne pystyy tunnistaan niitä tunteita ja tarpeita, joita kuolevalla potilaalla on. Ja sen pohjalta ruveta miettimään, minkälaista sen hoidon pitäis olla jos sen kerta pitää vastata niitä tarpeita. Ja tavoitteena on se potilaan hyvä olo, ei kärsimystä. Ja kärsimys on paljon laajempi kuin fyysinen kipu käsitteenä. - Ett se potilaan näkökulma kuitenkin enemmän.- Sieltä tulee hirveän paljon aineksia sieltä filmistä. Ettei varmasti kaikkia pysty käsitteleen. Mutta pitäis pystyä niitä, mitä ne oppilaat tuottaa.

Ohjaaja: Miten jäsennät sitä pitemmälle? Että sehän jää ainoastaan, että sulla on se, mitä opiskelijat tuotti. Mikä on tavallaan se teoreettinen viitekehys, mihin kytket ne. Että se ei oo vaan se toisto, että nyt tuotitte tunteista näitä ja tarpeista näitä Että mikä tulee se uusi näkökulma siihen opiskelijoiden tuotokseen.

\section{Toteutusvaihe (11. toukokuuta):}

Opettajaopiskelija: Viime tunnilla tuli esille ne erot, mitä on kuolevan potilaan hoidossa ja muuten potilaan hoidolla. ... Elikkä tuotitte hoidon tavoitteeksi potilaan hyvän olon, ei kärsimystä. Tänään katsotaan kuolevan potilaan hoitoa potilaan näkökulmasta. ... Eli havainnoitte videolta kuolevan potilaan tunteita ja tarpeita. Minkälaisia tunteita tämä potilas ilmaisi?

Oppilas: Voimakkain tunne oli sosiaalinen

Opettajaopiskelija: Liitätte tämän lapsiin eikö vaan? Miten hän tätä toi esille?

Oppilas: Varsinkin näihin lapsiin sellainen ahdistus ja hätä.

Opettajaopiskelija: Elikkä syyllisyyttäkin. Tuo on lähinnä kasvamista. Mitä teillä heräsi, mikä tunne nousi sieltä voimakkaimmin?

Oppilas: Alussa kun piti odottaa tulosta, niin se aiheutti pelkoa. Se odotusaika oli siinä mielessä positiivinen, että siinä pysty eroamaan niistä asioista, valmistautumaan tulevaan.

Opettajaopiskelija: Eli tässä tunteessa oli positiivinen ja negatiivinen. Miten panisimme tämän tunteen? Odotusta tulevasta vai pelkoa tulevasta?

Oppilas: Varmaan paha mieli siitä, että kukaan ei alkanut silloin sanomaan. Sen piti yö olla yksin ja miettiä sitä asiaa. ... Tuossa pitäisi käytäntöä muuttaa jotenkin, jos ei saada lääkäriä sinne heti kertomaan, niin pakko sille olisi jonkun kertoa.

Oppilas: Ehdottomasti pitäisi vaivautua sen verran, että siinä on kirurgi heti, kun se herää tai alkaa kyseleen.

Opettajaopiskelija: Mikä oikeus on hoitajalla kertoa? Mitä voi kertoa ja mitä varten on lääkärit? Mitä hoitajana olisitte voinut tehdä, että näitä tietoja olisi saanut?

Oppilas: Meille on puhuttu, ettei saada löydöksestä sanoa mitään. ... Jos se on ihan varma juttu, sen hoitajankin pitäisi pystyä sanoo potilaalle,

että lääkäri kertoo tarkemmin.

Opettajaopiskelija: ... Ei meidän tarvitse suoraan hoitajana sanoa, että teillä on tämä, vaan voi sanoa sen asian muutenkin potilaalle. Tuoda esille, että tarkempaa tietoa vielä saat

Oppilas: Sekin on ristiriitaista, jos potilas ei tiedä. En sano, mutta viestitän sen muuten

Opettajaopiskelija: Ihan sanallisesti jotenkin sen voi viestittää hoitajanakin. Eihän sitä voi peittää olemuksestaan. Kyllä sen varmasti näkee, ja potilaat on hyvin herkkiä, ne huomaa sen. ... Hoitajana voisi yrittää saada sitä kirurgia paikalle aikaisemminkin. Oppilas: Voi olla sellainen käytäntö mahdottomuus, että sen kirurgin saa sinne. Pitäisi se käytäntö muuttua jotenkin, että joku toinen pystyisi kertomaan. Opettajaopiskelija: Mitäs teillä? Minkälaisia tunteita näiden lisäksi tunnistitte potilaalla?

Suunnitteluvaiheessa itsehoidollinen hoitotyön ääni näkyy opettajaopiskelijan korostaessa potilasnäkökulmaa ja nimetessä oppimistehtäväkseen kuolevan potilaan tunteiden ja tarpeiden tunnistamisen sekä niihin vastaamisen. Edellisestä esimerkistä poiketen opettajaopiskelija valitsee hoitotyön toteuttajaksi potilaan hoitajan asemesta. Tästä osoituksena on myös se, ettei opettajaopiskelija käytä suunnitteluvaiheessa ryhmän yhteistä kuolevan potilaan hoidon mallia oman oppimisensa apuvälineenä. Hän ei rajaa dialogioppimisen lähtökohdaksi keskeisiä hoitotyön auttamismenetelmiä kuolevan potilaan psyykkisessä perushoidossa. Hän ei näin jäsennä ennalta potilasesimerkin opetuksellista käsittelyä, vaikka ohjaaja painottaa opettajaopiskelijan aktiivista osuutta teorian ja käytännön yhdistämisessä. Näin hän rakentaa suunnitteluvaiheessa oppimisen yhteistä kohdetta pelkästään empiirisellä tasolla.

Toteutusvaiheessa opiskelijat katsovat videon syöpäsairaasta potilaasta. Myös toinen opetustapahtuma käynnistyy induktiivisesti, kun opettajaopiskelija pyytää oppilaita luettelemaan videolta havainnoimiaan kuolevan potilaan tunteita ja tarpeita. Hoitotyön arkitodellisuutta ja sieltä nousevia ongelmia ei rajata näin alkuvaiheessa yhteisen oppimisen kohteeksi. Opettajaopiskelija ei myöskään tuo esiin keskeisiä hoitotyön auttamismenetelmiä yhteisen tavoitteen (hyvän kuoleman, ei kärsimystä) saavuttamiseksi, vaan hyväksyy opiskelijoiden vastaukset sellaisenaan. Reflektiivinen dialogi näkyy hänen lau- 
sumissaan oppilaiden vastausten toistona, myötäilynä ja laajentamisena. Tilanne kärjistyy, kun sairaanhoidon oppilaat kyseenalaistavat hoitotyön arkirutiineja kuolevan potilaan psyykkisessä hoidossa ja vaativat hoitokäytäntöjen uudistamista. Heidän näkökulmastaan itsehoitoajattelun ääni lisää potilaan kärsimystä, koska hänet jätetään epätietoiseksi sairautensa luonteesta kriittisessä vaiheessa.

Opettajaopiskelija joutuu vaikeaan tilanteeseen ristiriidan aiheuttavassa "kaksoissidostilanteessa" (Bateson 1972), jossa vastakkain on kaksi ääntä, hoitotaito ja itsehoito. Oppilaat vaativat uutta tietoa oman toimintansa tueksi, mutta ristiriitaa on vaikea ratkaista rikkomatta tietoisesti hoitoyhteisön sääntöjä. Niinpä opettajaopiskelija yrittää käynnistää reflektiivisen dialogin mukaisesti oppilaiden keskinäistä dialogia siinä kuitenkaan onnistumatta. "Kaksoissidoksen" aiheuttavaa ristiriitatilannetta on opetustapahtuman aikana vaikea hyödyntää jaetun tietämyksen muodossa, koska se edellyttäisi Batesonin (1972) mukaan koko käsiteltävän ongelman uudelleentulkintaa ja näin ollen ennen kaikkea hoitajan ammatillisen vastuun käsittämistä laaja-alaisesti. Kuolevan potilaan tunteiden ja tarpeiden systemaattinen jäsentäminen hoitotieteellisestä näkökulmasta jää oppitunnilla vähäiseksi, koska opettajaopiskelija ei pysty hyödyntämään ristiriitatilanteen tuottamaa moniäänisyyttä.

\section{Lopuks i}

Artikkelissa on kuvattu dialogioppimisen monimuotoisuutta opetusharjoittelun erilaisissa käytänteissä. Dialogioppimisen etu on se, että jokainen siihen osallistuva voi tuoda keskustelun kautta ryhmän käyttöön omaa asiantuntemustaan sekä oppia toisiltaan. Dialogioppimisen tuloksena yksilö tulee tietoiseksi niistä moninaisista tavoista, joilla arjen ongelmia voidaan ratkoa. Ryhmä tai yksilö voi ylittää kohtaamansa ristiriidan ja tarkastella sitä täysin uudesta näkökulmasta. Tällöin dialogi muodostuu välineeksi ymmärtää paremmin arkitodellisuutta ja samalla myös itseään suhteessa siihen. Artikkelissa kuvatussa esimerkissä opettajaopiskelija pystyi ryhmädia- login tuottaman tiedon ja yksilöllisen oppimisensa tuloksena jäsentämään palovammapotilaan hoidon kokonaisuutta tarkoituksenmukainen hoito henkilökohtaisena tavoitteenaan. Tämän käsitteen avulla hän rajasi turhat toimenpiteet kuolevan potilaan hoidosta pois kehittäen samalla omaa ammatillista osaamistaan eli itsensä johtamista. Tämä tapahtui kriittisen, arkikäytäntöjä kyseenalaistavan dialogimuodon kautta.

Dialogioppiminen ei ole helppoa. Se edellyttää kykyä asettua avoimeen suhteeseen, halua toisen kohtaamiseen ja myös itsensä paljastamiseen. Erityisen vaativaa se on silloin, kun siihen osallistuvat asettuvat vastakkain toisten eriävien näkökulmien ja vallitsevien käytänteiden kanssa. Ristiriitaiset näkemykset ovat helposti henkilökohtaistuneet ja ne on tulkittu erityisesti tiimeissä pikemminkin dialogin uhkana kuin rikkautena. Dialogin osapuolet eivät ole uskaltautuneet asettua avoimeen suhteeseen, koska kriittisyyden on koettu helposti kohdistuneen toisen tietämyksessä olevien aukkojen paikantamiseen. Epäonnistuneiden dialogien eli monologien keskeisiä piirteitä onkin usein ollut toisen yksilön vakuuttuneeksi saaminen omien näkemysten oikeudellisuudesta. Dialogin tavoitteena on tällöin pidetty yksimielisyyden saavuttamista keskustelun kohteena olevasta asiasta. Dialogioppimisesta voidaan kuitenkin puhua vasta sitten, kun ryhmä tai yksilö tarkastelee arjen ongelmatilanteita, esimerkiksi hoitajan ammatillista kasvua, ei vain omista näkökulmistaan vaan systemaattisena kokonaisuutena suhteessa sitä ympäröivän hoito-organisaation muihin tekijöihin.

\section{Lähteet}

BAHTIN, M. M. (1981). The dialogic imagination: four essays by M. M. Bahtin. Toimittanut M. Holquist. Austin. University of Texas Press.

BAHTIN, M. M. (1987). Speech genres \& other late essays. Austin. University of Texas Press.

BATESON, G. (1972). Steps to an ecology of mind. New York. Ballantine Books.

BURBULES, N. C. (1993). Dialogue in teaching. Theory and practice. New York. Teachers College Press.

DRAPER, S. \& Anderson, A. (1991). The significance of dialogue in learning and observing learning. Computers \& Education 17, 93-107.

ENGESTRÖM, R. (1999). Toiminnan moniäänisyys. 
Helsinki. University Press.

ENGESTRÖM, Y. (1987). Learning by expanding. Helsinki. Orienta-Konsultit.

ENGESTRÖM, Y., Engeström, R. \& Kärkkäinen, M (1995). Polycontextuality and boundary crossing in expert cognition: learning and problem solving in complex work activities. Learning and Instruction 5, 319-336.

FERNANDEZ-BALBOA, J.-M. \& Marshall, J. P. (1994) Dialogical pedagogy in teacher education: toward an education for democracy. Journal of Teacher Education 45, 172-182.

GROSZ, B. J. (1981). Focusing and description in natural language dialogues. Teoksessa A. K. Joshi, B. L. Webber \& I. A. Sag (toim.) Elements of discourse understanding. Cambridge. Cambridge University Press, 84-105.

HAKKARAINEN, P. E. \& Janhonen, S. (1997). Teaching practice as a testbench of learning in Master's degree education for nurse teachers in Finland. Nurse Education Today 17, 454-462

HAKKARAINEN, P., Helenius, J. \& Jääskeläinen, P. (1999). Ammatinhallinnan kehittäminen oppivassa organisaatiossa. Jyväskylän yliopisto. Koulutuksen tutkimuslaitos. Työpapereita n:o 8.

JANHONEN, S. \& Pyykkö, A. (1996). Kehittyvän hoitotyön malli. Porvoo: WSOY

JOHNSON, G. (1997). Reframing teacher education and teaching: from personalism to post-personalism. Teaching and Teacher Education 13, 815829

KAUPPI, A. (1993). Mistä nousee oppimisen mieli? Kontekstuaalisen oppimiskäsityksen perusteita. Teoksessa A. Kajanto (toim.) Aikuisten oppimisen uudet muodot. Kohti aktivista oppimista. Vapaan sivistystyön 34. vuosikirja. Helsinki. Kansanvalistusseura, 51-109

LAVE, J. (1993). The practice of learning. Teoksessa S Chaiklin \& J. Lave (toim.) Understanding practice. Perspectives on activity and context. Cambridge. University Press, 3-32.

MARKOVA, I. \& Linell, P. 1996. Coding elementary contributions to dialogue: individual acts versus dialogical interactions. Journal for the theory of social behaviour 26, 353-373.

MATUSOV, E. (1996). Intersubjectivity without agreement. Mind, Culture and Activity 3, 25-45.

MEZIROW, J. (1995). Uudistuva oppiminen. Krittinen reflektio aikuiskoulutuksessa. Helsingin yli- opiston Lahden tutkimus- ja koulutuskeskus.

NOPPARI, E., Huhtinen, A., Sillanaukee, T. \& Virta, M. (1996). Ihmisen hoitamisen kiehtovuus. Lähtökohtia kohtaamiseen dialogisessa yhteistyötilassa. Helsinki. Kirjayhtymä. Studia.

PRAWAT, R. S. 1996. Constructivisms, modern and postmodern. Educational Psychologist 31, 215 225.

ROGOFF, B. (1995). Observing sociocultural activity in three planes: participatory appropriation, guided participation, and apprenticeship. Teoksessa J. V. Wertsch, P. Del Rio \& A. Alvarez (toim.) Sociocultural studies of mind. Cambridge. University Press, 139-164.

SARJA, A. \& Janhonen, S. (1999). Dialogioppimisen analyysi hoitotyön opetus- ja oppimisprosessin suunnittelussa. Hoitotiede 11 (2), 53-62.

SARJA, A. (2000). Dialogioppiminen pienryhmässä. Opettajaksi opiskelevien harjoitteluprosessi terveydenhuollon opettajankoulutuksessa. Jyväskylän ylipisto. Jyväskylä Studies in Education, Psychology and Social Research 160

SENGE, P. (1990). The Fifth Discipline: the art and pracice of the learning organizations. New York. Doubleday Currency.

TILLEMA, H. H. (1997). Reflective dialogue in teams: a vehicle to support belief change in students teachers. European Journal of Teacher Education $20,283-296$

VELLA, J. (1994). Learning to listen, learning to teach. The power of dialogue in educating adults. San Francisco. Jossey-Bass.

VOLOSINOV, V. 1990. Kielen dialogisuus. Tampere Vastapaino.

VYGOTSKY, L. S. (1978). Mind in society: The development of higher psychological processes. Cambridge. Harvard University Press.

Artikkeli saapui toimitukseen 4.4.2000.

Se hyväksyttiin julkaistavaksi lausuntojen saannin jälkeen huhtikuussa. Kirjoittajan väitöskirja Dialogioppiminen pienryhmässä tarkastettiin Jyväskylän yliopistossa 18.2. vastaväittäjänä professori Hannele Niemi. 